\title{
THE WHOOPING CRANE IN SASKATCHEWAN
}

by Fred W. Lahrman, Saskatchewan Museum of Natural History, Regina

Southern Saskatchewan is a regular stop-over place for the Whooping Crane in its spring and fall migrations. In the spring the cranes rest during their last main stop before they continue to their nesting grounds. In the fall these same areas provide the first main stop on their 1800-mile return from Wood Buffalo Park to the wintering grounds in the Aransas Refuge in Texas.

Because Saskatchewan lies in the rather narrow flyway of the cranes and we are therefore in a particularly favored location for observing them during their migration, we became (almost accidentally perhaps) interested in the status of the birds and have since been moved to assume a certain responsibility for the protection of this endangered species. From the time when Fred G. Bard* became curator of the Saskatchewan Museum of Natural History in the 1930s the Museum has played an important role in the Whooping Crane's fight for survival. Mr. Bard became an active member of the International Whooping Crane Conservation Association which was formed to prevent the extinction of America's largest and rarest bird. At the Museum, Mr. Bard, who took both a professional and a personal interest in the project, established the policy of publicizing the plight of the crane; he also sought the co-operation of hunters and others whom he asked to report observations that could be field-checked by his staff. This procedure enabled Museum personnel to be-

*Fred Bard was the recipient of an honorary doctor of laws degree from the University of Saskatchewan, Regina, May 15, 1970 (see article on Dr. Bard in Blue Jay 28:146-147, December, 1970).

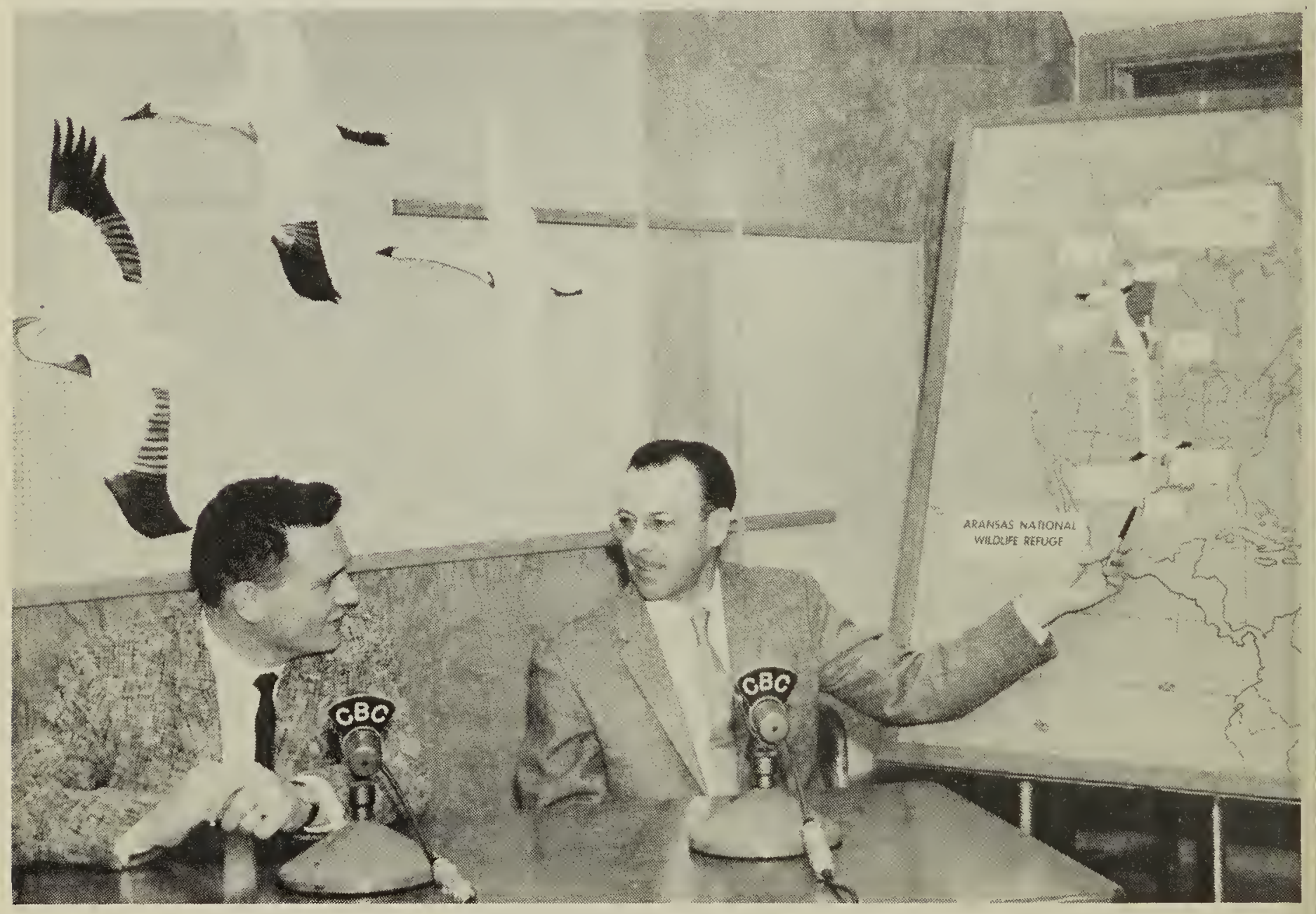

Fred Bard publicizing the plight of the Whooping Crane during an interview with CBC announcer Dave Cruickshank 


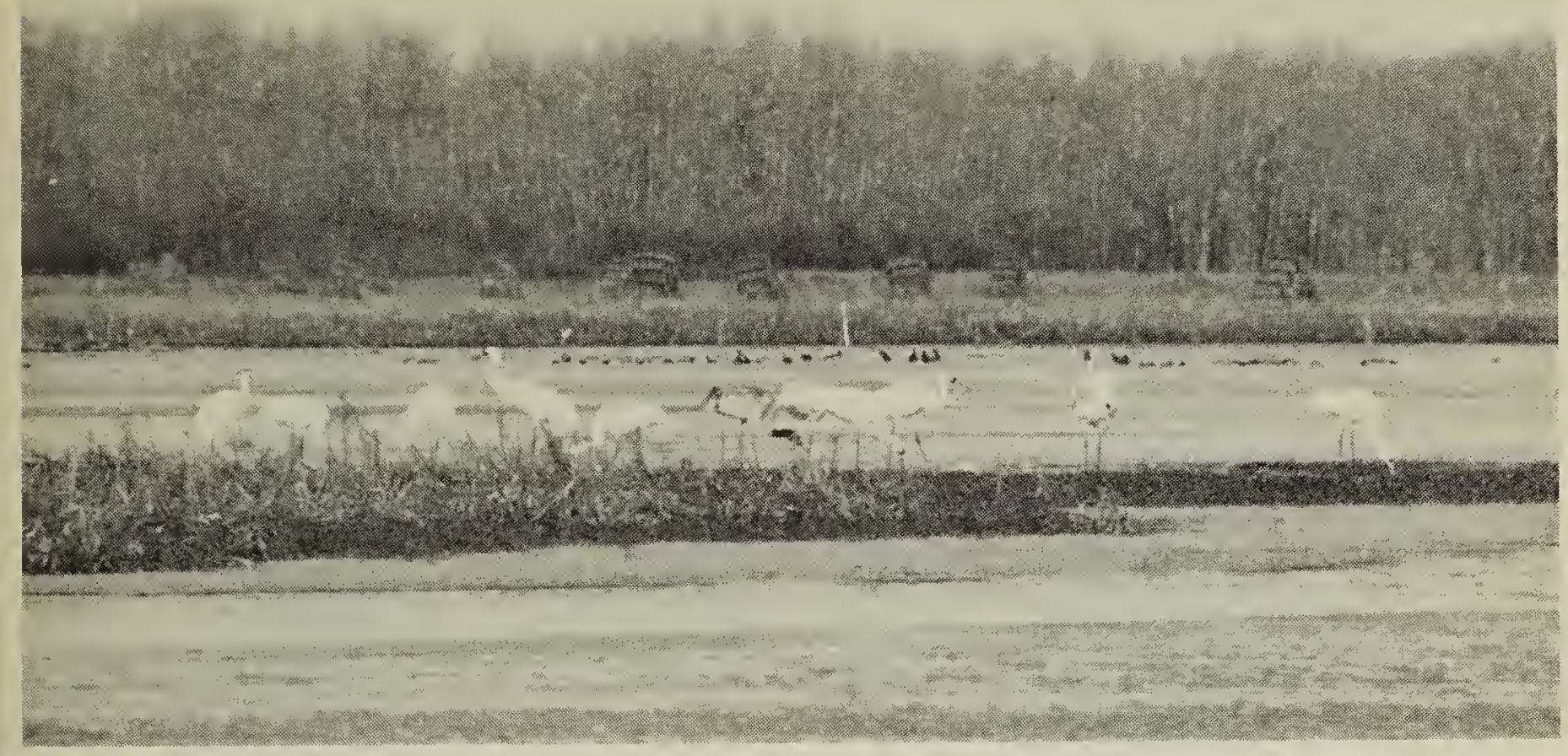

Museum Photo by F. W. Lahrman

Eleven Whooping Crane, including one juvenile, Glaslyn, October 15, 1969

come familiar with the behaviour and habitat preferences of the Whooping Crane. Certainly, the sight of these majestic birds during their migrations was unforgettable. One realizes how rare a treat it was to see a Whooping Crane when one considers that in 1941, with a mortality rate of 50 per cent, the Aransas migratory flock was reduced to 15 birds - a number that surely indicates that the species was close to extinction. At that time, no one could have hoped to see such a large number of birds as I was fortunate enough to photograph at Glaslyn in the fall of 1969 .

As I have said, each spring and fall Mr. Bard prepared informative articles for the local press publicizing the plight of the Whooping Crane and asking everyone to ensure the birds safe passage through Saskatchewan (many articles included illustrations to help people distinguish the Whooping Crane from other large white birds). He also elaborated on the history of the Whooping Crane. For instance in one article (Blue Jay, 16: 11-14, 1958) Mr. Bard recalls the two nests found 36 years earlier by Neil Gilmour near Baliol (May 19, 1922), and by Fred Bradsahw at Muddy Lake (May 28, 1922). These were the last nests identified in southern Saskatchewan. Not until 1954 were the nesting. grounds in Wood Buffalo Park, N.W.T., discovered. Meanwhile, the small non-migratory flock in Louisiana rapidly declined after a hurricane nearly wiped it out in 1940 , and the last bird of that flock perished in 1950. The Aransas National Wildlife Refug'e, established in December, 1937, included the wintering grounds of the migratory birds and has been an important factor in the survival of the Whooping Crane but the population for many years remained perilously low. Some years were particularly disastrous. In the years $1950,1951,1952$ (Fig. 1) losses were 7, 11 and 6 respectively. In 1954, three adults were lost and no young reached Aransas. In December, 1954 there were only 21 birds in the wild flock.

Public interest in conservation of the species, built up by the frequent news releases, and by the enthusiasm and optimism of conservationists like Mr. Bard, now assures the bird of fairly safe passage over its long migration route. Currently, according to the December 1971 count, the Aransas flock numbers 59. There is also a captive flock of 21 (17 at Patuxent, three at Audubon Zoo in 
New Orleans and one-Crip-in the San Antonio Zoo in Texas). This captive flock is mainly the result of a new program of removing one egg from each nest in Wood Buffalo $\mathrm{Na}$ tional Park and hatching and rearing the young at Patuxent in Maryland. The program began in June 1967 when Ernie Kuyt, Canadian Wildlife Service biologist, collected six eggs.

The present total of 80 Whooping Cranes is encouraging, but we are far from having saved the species from extinction. The education of the public must be continued because the Whoopers are not quite the wild and wary birds they used to be, perhaps because they have faced less gunfire in recent years. I have, for instance, seen them pass low over groups of people, cars and buildings. They can thus be very vulnerable to the irresponsible vandal with a gun; how vulnerable is shown by an incident last spring in which four Whistling Swans were shot and left lying in a field near the Moose Jaw Creek.
And the birds face many hazards. The breeding area is so far north that the nesting season is extremely short and subject to cold and unfavorable conditions. Then, too, one needs only to scan newspapers and magazines to see what is happening to environment and wildlife the world over. Almost any setback that would normally be absorbed by a common species could eliminate the Whooping Crane.

The plan underway at the Patuxent Research Centre to establish a new Whooper flock is a major step in the right direction. It should be borne in mind that the Whooping Crane normally lays only two eggs per clutch and rarely raises more than one young. As only one egg has been taken from any one nest, this has caused no loss to the wild flock (Fig. 1) and it has actually produced a bonus group of young to be added to the annual migrant young. It is imperative to continue this program now while the wild flock is large enough to give six or more eggs to the program each

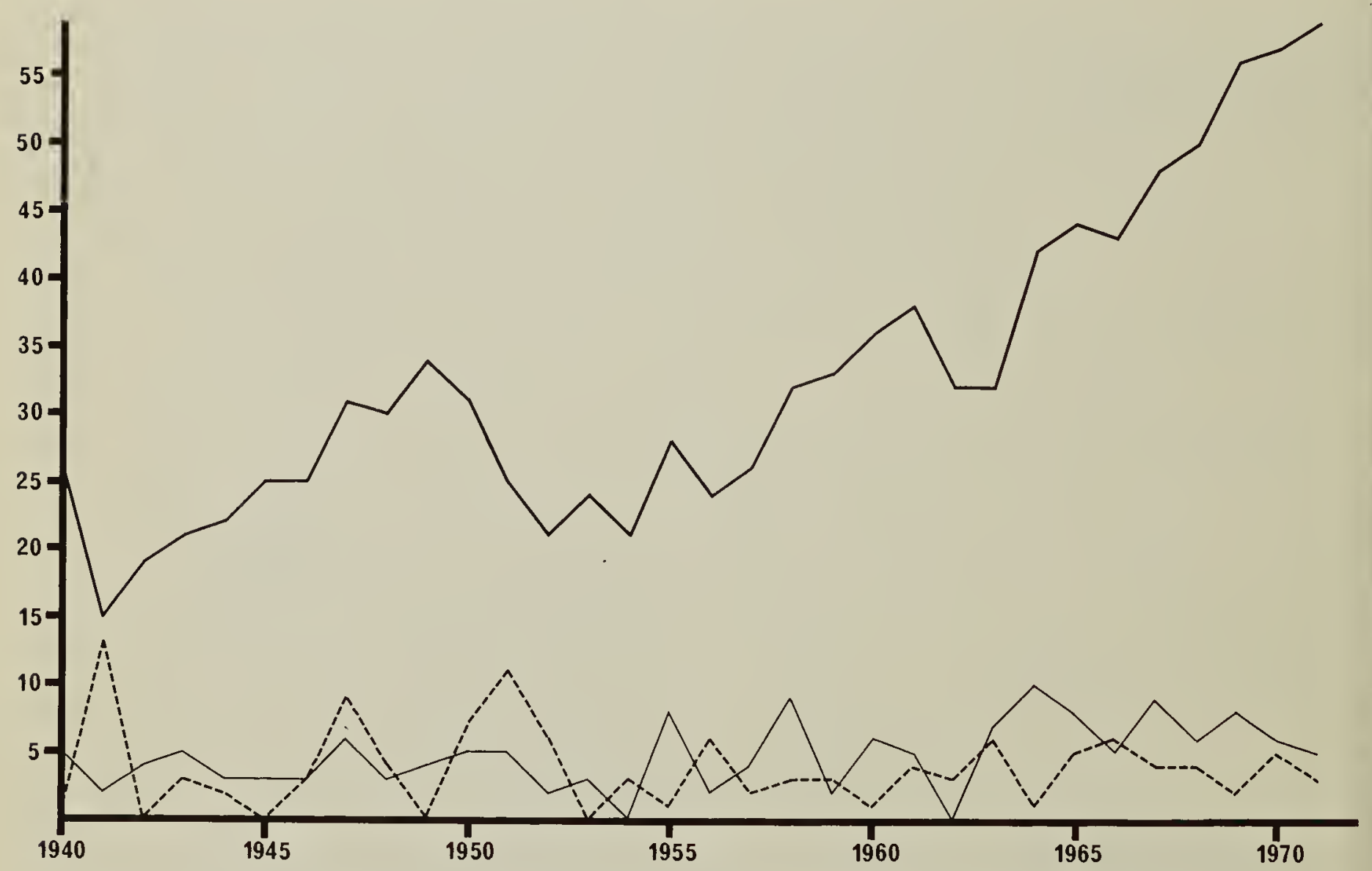

Fig. 1. The upper line denotes the total Aransas Refuge December populations of the Whooping Crane. The lower solid line represents the number of young added to the population each year. The broken line represents the annual loss of adults. 


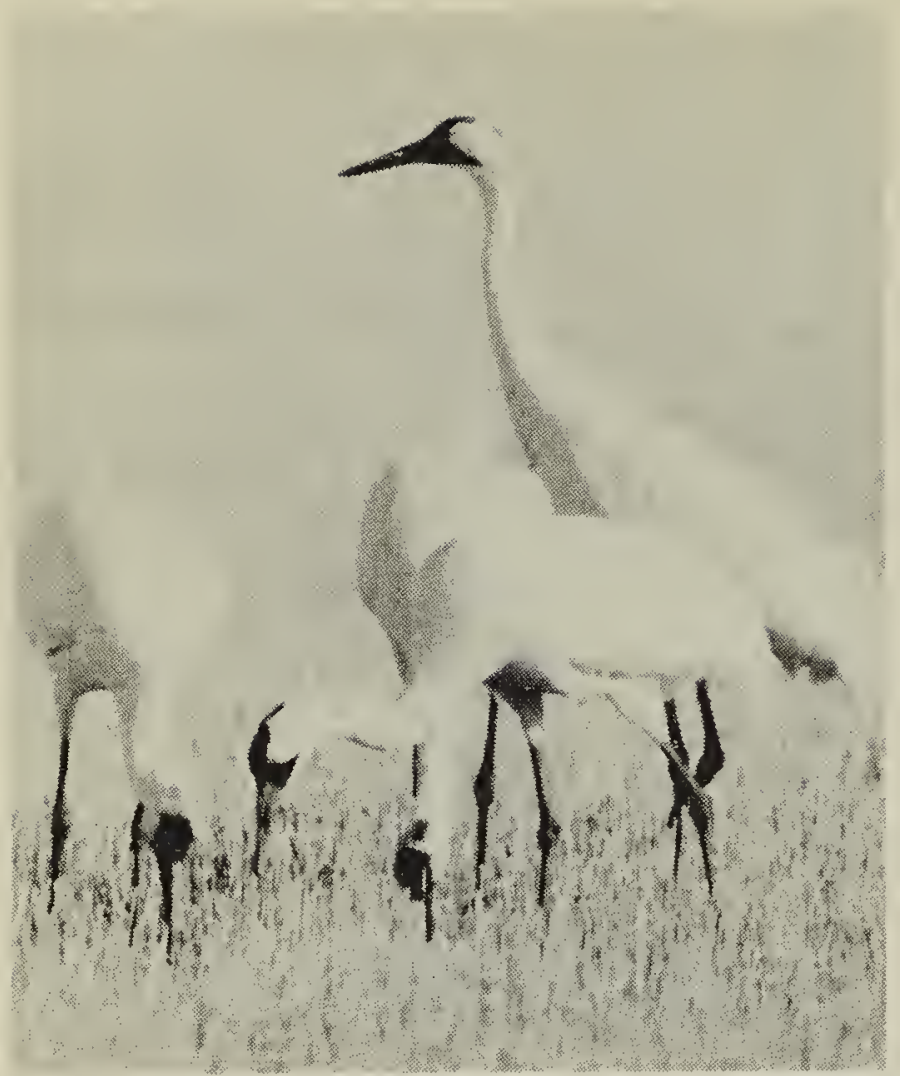

Photo by F. W. Lahrman

Whooping Crane near Moose Jaw, October, 1965

established. To facilitate the selection of mates I would suggest that unmated birds be released in a large, rigidly protected enclosure (perhaps several hundred acres of suitable marsh land formerly occupied by Whooping Crane would fulfill the requirements). Breeding Whooping Cranes are very territorial and will not tolerate any other crane near their nesting area; therefore, mated pairs must be removed to become established in another suitable location where they will not be disturbed by sight or sound of other Whooping Cranes. This is the considered opinion of Fred Bard who is convinced that Jo and Crip failed to nest because the four young of previous years (now adults) were kept in pens near by.

In attempts to increase the total population, then, every captive Whooping Crane must be used to the best possible advantage. Not only must the birds be given the opportunity to mate but attempts must be made to reduce inbreeding to a minimum. When the birds have selected mates, they must be given suitable territory within which they can reproduce. Since there was once a resident non-migratory flock in Louisiana, and since a number of wildlife refuges in the state could be utilized, I believe that a nonmigratory flock might be established there as soon as mated breeding pairs become available among the captive birds. Since the Whooping Crane nested in southern Saskatchewan as recently as 1922, and since the Wood Buffalo Park must be a hazardous nesting area for the Whoopers, I would like to see a marsh in southern Saskatchewan designated as a potential breeding area for a second migratory flock. Many of these recommendations have been made on numerous occasions by Fred Bard on the basis of his personal observations and evaluation of reports.

I would like to pay tribute to all those who have worked so diligently to preserve the Whooping Crane, and to the public whose concern and support have no doubt tipped the balance in favour of the Whooping Crane and enabled it to reach the number we have today. The future holds some promise for the Whooping Crane but I would urge that additional projects be established to provide more opportunities for success and to use each precious year to its fullest potential.

\section{MEETING IN REGINA}

The International Whooping Crane Conservation Association is holding its 1972 meeting in Saskatchewan. There will be two days (September 18 and 19) of papers and films and then a field trip to Last Mountain Lake to see Sandhill Crane and, hopefully, Whooping Crane on migration through Saskatchewan. Members of SNHS are invited to register and to attend. Program details may be obtained from the Museum, Wascana Park, Regina.

Join the Association and help save the Whooping Crane. 